\title{
The emergence of an ethic of care in rural Kenyan schools? Perspectives of teachers and orphaned and vulnerable pupils
}

Article

Accepted Version

Skovdal, M. and Evans, R. (2017) The emergence of an ethic of care in rural Kenyan schools? Perspectives of teachers and orphaned and vulnerable pupils. Children's Geographies, 15 (2). pp. 160-176. ISSN 1473-3285 doi:

https://doi.org/10.1080/14733285.2016.1214236 Available at https://centaur.reading.ac.uk/65847/

It is advisable to refer to the publisher's version if you intend to cite from the work. See Guidance on citing.

To link to this article DOI: http://dx.doi.org/10.1080/14733285.2016.1214236

Publisher: Taylor \& Francis

All outputs in CentAUR are protected by Intellectual Property Rights law, including copyright law. Copyright and IPR is retained by the creators or other copyright holders. Terms and conditions for use of this material are defined in the End User Agreement.

www.reading.ac.uk/centaur 
Central Archive at the University of Reading

Reading's research outputs online 


\title{
The emergence of an ethic of care in rural Kenyan schools? Perspectives of teachers and orphaned and vulnerable pupils
}

\author{
Morten Skovdal* \\ Department of Public Health, University of Copenhagen, Øster Farimagsgade 5, 1014 \\ Copenhagen, Denmark. \\ Email: m.skovdal@gmail.com \\ Telephone: +4535337360 \\ Ruth Evans \\ Department of Geography \& Environmental Science, University of Reading, Reading, \\ Berkshire, RG6 6AH, UK. \\ Email: r.evans@reading.ac.uk \\ Telephone:+44(0)1183787755 \\ ${ }^{*}$ Corresponding author
}

\begin{abstract}
In the context of HIV, there is considerable debate about the role of schools and teachers as potential sources of care and support for vulnerable children. This qualitative research examines 'care' as experienced and practiced by pupils and teachers in rural Western Kenya. In primary and secondary schools, interviews were conducted with 18 teachers and 57 orphaned and vulnerable pupils, alongside Photovoice. Drawing on thematic analysis and an 'ethic of care' theoretical perspective, we unpack the informal caring practices of teachers within resource-constrained settings. The research provides glimpses of schools as spaces of care, participation and support for orphaned and vulnerable pupils. Recognising and providing institutional support for the development of an ethic of care in schools may help to tackle the considerable educational barriers facing girls and boys who are orphaned and vulnerable and move 'care' closer towards the centre of educational policy and practice in the global South.
\end{abstract}

Key words: Orphaned and vulnerable children; education spaces; gender discrimination; ethics of care; HIV epidemic; rural Kenya

\section{INTRODUCTION}

The education system, by virtue of its large institutional network of pedagogically trained adults who regularly interact with children, is in a unique position to offer care and support for marginalized children and youth (Theron and Engelbrecht 2012). Researchers, policymakers and practitioners working in sub-Saharan Africa increasingly regard schools as potential 
spaces of care and support. We argue, however, that such efforts must be located within a broader discussion of how schools and teachers respond to the hardships experienced by orphaned and vulnerable children in high HIV prevalence, resource-constrained communities. In this context, we seek to unpack intricate caring practices within schools in low resource, high HIV prevalence communities and examine the possibilities and limits for teachers to go beyond their call of duty (i.e., providing education) to care for vulnerable pupils.

Although there is a relative paucity of geographies of schooling in the global South, and debates in the global North often differ considerably from the concerns of researchers working in resource-limited contexts, there is widespread consensus that schools are "sites of preparation" for children's future roles (Collins and Coleman 2008, 295). Ansell (2008, 802) argues that while schools in sub-Saharan Africa "have long supplemented families in delivering generational reproduction", their role is usually focused narrowly on preparing new generations of workers. Educational institutions have tended to regard children as 'human becomings' who need to be instructed in preparation for productive roles in adulthood, rather than focusing on them as 'human beings' who actively contribute to society in the present and may have needs for 'care and support', rather than just 'learning' (Foster, Addy, and Samoff 2012). This study, and a growing body of literature, suggests that the role of schools and caring practices of teachers may be changing in the context of HIV and resourceconstraints in Sub-Saharan Africa.

\section{Schools as spaces of care and support?}

Orphaned and vulnerable children in sub-Saharan Africa experience multiple barriers to their education and well-being, including poverty, neglect, young caregiving and unfriendly school environments (Campbell et al. 2014; Evans, 2012a; Skovdal 2008; Watkins et al. 2014). Girls and young women are particularly disenfranchised. 'Girl-unfriendly' school environments and gender disparities in education, particularly at secondary level in sub-Saharan Africa, continue to undermine efforts to address Sustainable Development Goals 4 and 5 and other development targets (UNICEF 2011).

Although literature on the impacts of HIV in Eastern and Southern Africa has focused predominantly on orphaned children as recipients of care within the home (Van Blerk and Ansell 2007) or community (Skovdal et al. 2013), policymakers, practitioners and researchers are now beginning to explore children's and teachers' care interactions within school spaces (cf. Skovdal and Campbell 2015). This is exemplified by UNICEF's (2009) notion of 'child- 
friendly schools' as well as the growing number of programmes designed to equip teachers to better respond to the needs of orphaned and vulnerable children (Ferreira and Ebersöhn 2011), and to empower children and youth to withstand difficult circumstances (Fonner et al. 2014; McLaughlin et al. 2015).

The few studies that have investigated the care potential of teachers in high HIV prevalence, resource-constrained settings present mixed evidence. Some reveal teachers' 'hidden pastoral care' role (Bhana et al. 2006; Mwoma and Pillay 2015; Nordveit 2010) and their ability to enhance children's coping and resilience (Khanare 2012; Theron and Engelbrecht 2012). Such findings contrast, however, with Evans' (2012a) work in Tanzania and Uganda, which found teachers to be unsympathetic when young people tried to explain about their caring responsibilities and pupils continued to be punished for lateness and concentration problems in class. In Zimbabwe, Campbell and colleagues (2016) found that while teachers were aware of pupils' needs, loss of morale, problems in their own lives and stigma meant that they were rarely in a position to translate this awareness into care. Campbell et al. (2015) argue that teachers' different responses are mediated by the absence or presence of solidarity within the school environment, opportunities for dialogue about HIV and the difficulties faced by affected learners, as well as the capacity of schools to build bridges and links with their local community and external actors.

Hoadley's (2007) analysis of South African education policies suggests that schools and teachers are explicitly charged with the responsibility of identifying, supporting and monitoring vulnerable children. She argues that we cannot expect resource-constrained schools and teachers in sub-Saharan Africa, who are already struggling to meet their educational mandate, to take on additional roles and responsibilities. Instead, she maintains that schools should be thought of "as sites through which support may be offered, rather than conceiving of support offered by schools themselves" (Hoadley 2007, 257). Whilst we agree with this argument, we are also sympathetic to Noddings $(2012,777)$ outright rejection of the idea that creating a nurturing and caring school climate is "on top of all the other demands". She argues that creating such a caring environment is a prerequisite for teaching.

These differing accounts illustrate an analogous debate about whether teachers can or should be expected to provide care and whether this conflicts with their role as educators. It highlights the urgent need to unpack the specific 'caring' practices of teachers within school spaces. Only by understanding the different forms of care provided by teachers, will we be able to answer broader questions concerning geographies of education, care and social reproduction: To what extent are teachers and schools in sub-Saharan African countries most affected by the HIV epidemic moving away from a narrow purpose concerned with 
'generational reproduction' towards an ethics of care, which seeks to meet the needs of children affected by HIV (Ansell 2008)? What are the parameters and limits of an emerging ethic of care?

\section{THEORETICAL APPROACH}

Since the late 1980s, masculinist understandings of moral reasoning that privileged individual autonomy and independence have been critiqued by feminist theorists, who have argued instead for a relational ethics of care that recognises human interdependencies and the need for care throughout the lifecourse (Lawson 2007; Tronto 1993). In this article, we draw on Tronto's conceptualisation of an 'ethic of care'1 to analyse interactions between teachers and pupils and discuss how teachers respond to the hardships and care needs of orphaned and vulnerable pupils. In contemporary democratic societies, care is increasingly professionalised, and institutions outside the home, including schools, are expected to perform caring duties that used to be met in the home (Tronto 2013). Yet 'care work' continues to be devalued, poorly paid, associated with the 'private' sphere, regarded as part of women's and girls' 'natural' nurturing roles and hence beyond the possibility for change. Tronto $(2013,10)$ argues that care should be the central focus of the political agenda and the key question should be "How, at every level, can we engage in caring with one another?". This requires a nuanced account of responsibility and ensuring that democratic citizens are as capable as possible of participating in this assignment of responsibilities (ibid.).

Previous studies have drawn on an ethics of care to explore the emotional dynamics of caring relations between children and parents/relatives living with HIV in homespace (Evans and Thomas 2009), to analyse the gendered, often interlinked 'taking care of' and 'caregiving' phases of the caring process that young people engage in following parental death (Evans 2014) or to demonstrate the potential contribution of an ethics of care to livelihood approaches (Hanrahan 2015). Few studies have used this theoretical approach to explore interactions between teachers and pupils in school spaces in the global South. This gap is at odds with calls for the education sector in countries most affected by the HIV epidemic "to be understood in relation to an ethics of care rather than the functionalist production of a future workforce" (Ansell 2008, 802).

Tronto's (1993) four-phase framework is useful in unpacking the specific dynamics of the caring process, interactions, notions of responsibility and other ethical values. Care is understood as both a practice and a disposition involving a complex interaction between socio-cultural and ethical values of care, the identities of those 'giving' and 'receiving' care, 
social (and in this case, educational) policy and practice, and wider political and economic structures and processes (Evans and Thomas 2009). The four phases are:

1. 'caring about', associated with attentiveness to the needs of others;

2. 'taking care of', associated with responsibility, which is culturally constructed;

3. 'care-giving', associated with competence to provide 'good care', including the availability of adequate resources;

4. 'care-receiving', associated with the responsiveness of the care-receiver to the care (Tronto 1993, 131-6).

'Good care' is based on the integration of these four phases of the caring process into an appropriate whole. This provides a useful framework for conceptualising pupils' and teachers' disposition and responsibility to care and analysing teacher-pupil relations, within a broader understanding of the ways that such interactions and practices are embedded in wider structural inequalities, gendered and generational relations and global processes.

\section{METHODOLOGY}

As this study seeks to unpack teacher-pupil relations and caring practices within the school environment, a qualitative research design was deemed most appropriate. The study was conducted in Siaya County of Western Kenya - a rural county disproportionately affected by malaria, HIV and water-borne diseases, worsened by inadequate health services. The HIV prevalence rate of Siaya has been estimated at $17.8 \%$, three times the national average of $5.6 \%$ (NACC 2014).

In collaboration with a local NGO, three study communities were selected because of their rural location, high HIV prevalence and poverty. Each community comprised one primary and one secondary school. The schools were poorly resourced and had high pupil-to-teacher ratios (1:49 in primary school and 1:27 in secondary school).

\section{Study participants and data collection}

Community guides from local community groups purposefully recruited a diverse group of orphaned and vulnerable pupils, teachers and community members through a combination of snowball and maximum variation sampling. Informed and written consent was obtained from all participants, including the guardians of participants under the age of 18 . 
Semi-structured in-depth interviews were facilitated with nine primary (mean age of 33 years, $34 \%$ female) and nine secondary school teachers (mean age of 28 years, $67 \%$ female). Thirty primary (aged 10-17, mean age of 13.5 years, 60\% female) and 27 secondary (aged $15-20$, mean age of $16.5,48 \%$ female) school pupils, locally defined as either orphaned (one or both parents had died) or living with a sick caregiver, completed a brief assessment questionnaire. This was used to ensure they met the criteria for 'orphaned and vulnerable children'; and to obtain basic background information on local support structures. The children were subsequently invited to participate in a Photovoice project (Wang and Burris 1997) and individual in-depth interviews. Due to household and school time commitments, not all the children were able to participate in both activities. Of the 57 orphaned and vulnerable pupils recruited for the study, 51 participated in Photovoice and 47 of these pupils participated in individual interviews (see Table 1).

\begin{tabular}{|c|c|c|c|c|c|}
\hline \multirow{2}{*}{$\begin{array}{l}\text { Participants and data collection } \\
\text { methods }\end{array}$} & \multicolumn{2}{|c|}{ Primary school } & \multicolumn{2}{|c|}{ Secondary school } & \multirow{2}{*}{ Tota } \\
\hline & Male & Female & Male & Female & \\
\hline \multicolumn{6}{|c|}{ Orphaned and vulnerable pupils $(n=57)$} \\
\hline Assessment questionnaire & 12 & 18 & 14 & 13 & 57 \\
\hline Photovoice & 12 & 14 & 12 & 13 & 51 \\
\hline In-depth interviews & 10 & 10 & 14 & 13 & 47 \\
\hline \multicolumn{6}{|l|}{ Teachers $(n=18)$} \\
\hline In-depth interviews & 6 & 3 & 3 & 6 & 18 \\
\hline
\end{tabular}

Table 1: Research methods used with the sample of participants

The first author trained and led three research assistants, proficient in the local Dholuo language, to collect data between May and December 2012. Photovoice was initiated through a workshop showing the pupils how to use disposable cameras and a discussion of the ethics of taking pictures and study objectives. The pupils were given two weeks to take pictures that show what life is like for school-going orphaned or vulnerable children as well as who or what supports them through their education. Cameras were then collected and pictures developed, with pupils receiving a copy to keep. At a second workshop, pupils were invited to choose six photographs they were happy to share with the research team, depicting: i) something or someone in school who makes them happy or sad; ii) something or someone who helps them attend school; iii) something they lack, need, or wish they had more of to improve their education or iv) the importance of education. If the pupils wanted to share a story or a scenario that they could not capture with the camera (because of limited 
time, ethical reasons or camera malfunction), they were encouraged to draw the scenario. They were subsequently invited to write short essays to accompany each of their six pictures, answering three questions: Why do you want to share this picture? What is the story that this picture tells? How does this story relate to your life and/or the lives of other children in your school?

This exercise generated a total of 224 pictures and 119 drawings, each accompanied by a written essay. Photovoice was not merely used to trigger more information about the topic, but to enable the children to be researchers of their own communities, and to use the themes emerging to shape the data analysis. In-depth interviews covered the following themes: dayto-day life and living arrangements of orphaned and vulnerable pupils, schooling experiences, the ways teachers and schools provided care and support. All interviews were digitally recorded. All data were anonymised and pseudonyms have been used throughout ${ }^{2}$.

\section{Data analysis}

Interviews and hand-written narratives were transcribed and translated into English before being imported into Atlas.Ti for coding and thematic network analysis (Attride-Stirling 2001). This paper does not seek to report on all of the codes and basic themes emerging from this analysis, but presents 27 dominant themes that shed light on the life circumstances of orphaned and vulnerable pupils and teachers' responses to challenges pupils faced. To synthesise the data and develop overarching interpretative themes, the 27 basic themes were arranged into eight 'organising themes', which in turn were summarized by four 'primary themes' (see Table 2), which structure the discussion of the findings. 
Table 2: Thematic network: Contextualising teachers' responses to the learning needs of orphaned and vulnerable pupils

\begin{tabular}{|c|c|c|}
\hline Primary Themes & Organising Themes & Basic Themes \\
\hline \multirow{9}{*}{$\begin{array}{l}\text { Barriers to } \\
\text { education: poverty, } \\
\text { young caregiving } \\
\text { and 'un-caring' } \\
\text { school spaces? }\end{array}$} & \multirow{3}{*}{$\begin{array}{l}\text { Difficulties meeting the } \\
\text { cost of education }\end{array}$} & 1. Pupils often live in poverty \\
\hline & & 2. Limited adult support \\
\hline & & 3. Temporary drop-outs and absenteeism \\
\hline & \multirow{3}{*}{$\begin{array}{l}\text { Pupils' contribution to } \\
\text { household survival } \\
\text { affects their education }\end{array}$} & 4. Pupils engage in casual labour \\
\hline & & 5. Pupils provide care for sick or elderly family members \\
\hline & & 6. Pupils have limited or no time to do home work \\
\hline & \multirow{3}{*}{$\begin{array}{l}\text { Everyday struggles } \\
\text { affect the concentration } \\
\text { and performance of } \\
\text { pupils }\end{array}$} & $\begin{array}{l}\text { 7. Poor concentration in school as they worry about } \\
\text { dependents }\end{array}$ \\
\hline & & 8. Hunger affects the concentration of pupils \\
\hline & & 9. Stigma, teasing and humiliation \\
\hline \multirow{9}{*}{$\begin{array}{l}\text { 'Caring about' and } \\
\text { 'taking care of' } \\
\text { orphaned and } \\
\text { vulnerable children } \\
\text { in schools? }\end{array}$} & \multirow{5}{*}{$\begin{array}{l}\text { Establishing a child's } \\
\text { home situation is a } \\
\text { prerequisite }\end{array}$} & 10. Teachers need to know the pupils background \\
\hline & & $\begin{array}{l}\text { 11. Pupils are reluctant to open up about their home } \\
\text { situation }\end{array}$ \\
\hline & & 12. Meetings with pupils and parents \\
\hline & & 13. Teachers visiting the homes of pupils \\
\hline & & $\begin{array}{l}\text { 14. Teachers communicating internally about vulnerable } \\
\text { pupils }\end{array}$ \\
\hline & \multirow{4}{*}{$\begin{array}{l}\text { Teachers and school } \\
\text { leadership showing } \\
\text { sympathy and } \\
\text { understanding }\end{array}$} & 15. Teachers recognizing their learning needs \\
\hline & & $\begin{array}{l}\text { 16. Teachers and school leadership showing flexibility to } \\
\text { support pupils }\end{array}$ \\
\hline & & $\begin{array}{l}\text { 17. Teachers initiating school activities that can support } \\
\text { pupils }\end{array}$ \\
\hline & & 18. Teachers encouraging students not to give up \\
\hline \multirow{4}{*}{$\begin{array}{l}\text { 'Care-giving' and } \\
\text { 'care-receiving': the } \\
\text { emergence of an } \\
\text { ethic of care in } \\
\text { Kenyan schools? }\end{array}$} & \multirow{4}{*}{$\begin{array}{l}\text { Teachers going beyond } \\
\text { the call of duty }\end{array}$} & 19. Teachers helping the pupil at home \\
\hline & & $\begin{array}{l}\text { 20. Teachers providing pupils with school items out of } \\
\text { own pocket }\end{array}$ \\
\hline & & $\begin{array}{l}\text { 21. Teachers paying for the fees or levies of some pupils } \\
\text { out of own pocket }\end{array}$ \\
\hline & & $\begin{array}{l}\text { 22. Teachers occasionally offer accommodation to } \\
\text { vulnerable pupils }\end{array}$ \\
\hline \multirow{5}{*}{$\begin{array}{l}\text { Competence to } \\
\text { care? constraints in } \\
\text { the support of } \\
\text { orphaned and } \\
\text { vulnerable pupils }\end{array}$} & \multirow{3}{*}{$\begin{array}{l}\text { Teachers not equipped } \\
\text { to deal with needs of } \\
\text { orphaned and } \\
\text { vulnerable pupils }\end{array}$} & 23. Inadequate staffing \\
\hline & & $\begin{array}{l}\text { 24. Teachers not in a position to respond to the learning } \\
\text { needs of OVC }\end{array}$ \\
\hline & & 25. Differential treatment \\
\hline & \multirow{2}{*}{$\begin{array}{l}\text { Emphasis on } \\
\text { performance }\end{array}$} & 26. Culture of support given to high performing pupils \\
\hline & & 27. Some teachers give up on poor performing students \\
\hline
\end{tabular}




\section{FINDINGS}

\section{Barriers to education: poverty, young caregiving and 'un-caring' school spaces?}

Many orphaned and vulnerable pupils struggle to meet the demands of school and sustenance. Participants spoke at length about their impoverished living situation, lack of food and inability to meet the costs of education, due to the fact that their relatives were either unable to work or engaged in low wage casual work. This often resulted in temporary school drop-out and reduced school performance, as explained by 15 -yearold Edmond, a secondary school pupil:

"Since there is nobody to pay my school fees, I am sometimes sent back home to get money whilst my classmates continue with their classes, this has lowered my performance."

In a neighbouring community, we found approximately $20 \%$ of orphaned children to experience high rates absenteeism in primary school (>12 days/term) compared to $3.5 \%$ of their non-orphaned peers (Skovdal et al. 2013).

Although primary education in Kenya is officially free of charge, schools, at their discretion, can add school levies to supplement shortfalls in running costs. In Siaya the yearly cost of primary education, including uniforms, books and school levies, comes to US\$85, which is beyond the means of many HIV-affected households. At US\$520 per year, secondary school costs are significantly higher, further entrenching barriers to education. Consequently, only 52.7 per cent of primary school students in Siaya transition to secondary school (GoK 2013).

In addition to representing a barrier to education, pupils reported that poverty made them stand out as a potential target for bullying. For some, visible signs of their poverty within 'uncaring' school spaces led to humiliating situations and teasing. Elias (aged 12) was embarrassed about the torn state of his school uniform, a highly visible, embodied sign of his poverty:

"This is a photo of my uniform (see Figure 1). I want to share this photo because it is the only uniform I have, it is torn and it is the one I wear when going to school. I feel embarrassed when I put it on. Parts of my body get exposed. Some children say bad things about me. This makes me sad and not wanting to go to school. Because of the embarrassment that my torn uniform causes me, my concentration and performance in school is poor." Elias, age 12, primary school pupil 


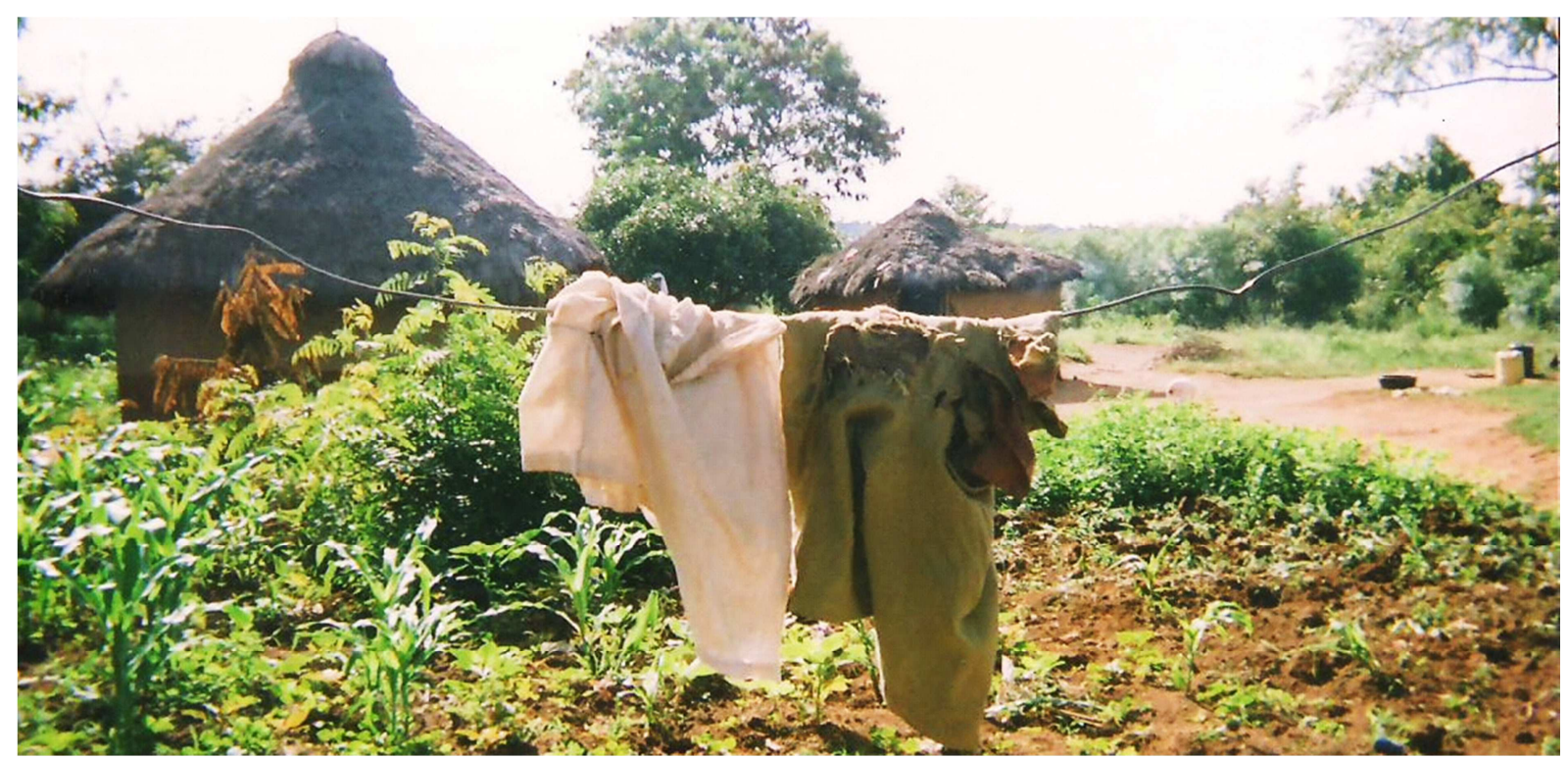

Figure 1

Similarly, 'girl-unfriendly' school environments, and a lack of sanitary towels, could also lead to embarrassing situations for secondary school girls, forcing them to go home from school early. Such experiences relate to wider concerns about gender disparities in secondary school participation, which are highest in sub-Saharan Africa and South Asia (UNICEF 2011).

Alongside poverty and financial pressures to meet schooling costs, young people's caring responsibilities could represent a further barrier to education. All but two study participants reported having specific caring responsibilities for either aging grandparents $(n=28)$, sick parents $(n=20)$, young or sick siblings $(n=5)$, or sick extended family members $(n=2)$. The amount of time spent caring varied significantly, from a couple of hours of week to some children reporting to care 'all day long'. This reflects the 'care-giving' phase of the caring process, which children sought to juggle with casual labour and long school days:

"Every day after school I have to go to people's farms to look for vegetables in order to get food, after which I will rush to my neighbour's farm to do some casual labour of weeding to get money to sustain my grandfather and me. After that I will go to the river to fetch water for cooking and bathing. I will then cook. This has made me not to perform well in school because I do not have enough time to do my studies" Teresa, age 15, primary school pupil

Although their caregiving roles varied according to the care needs of relatives, pupils, like 20year-old Gabriel, studying at secondary school, spoke of how they sometimes had to miss or 
drop out of school temporarily in order to provide care: "When my guardian is sick I absent myself from school to care for her at home." As Evans (2012a, 831) has observed amongst care-giving young people in Tanzania and Uganda, embodied time-space practices of caring often conflict with the linear rhythms of schooling and work, as well as the cyclical rhythms of everyday life, such as the body's daily needs for food, rest and sleep, and seasonal agricultural labour demands. Our research from Kenya confirms that the conflicting pressures of caring responsibilities and school resulted in time scarcity which could have negative impacts on young people's educational outcomes.

Indeed, the vast majority of primary (89\%) and secondary school pupils (75\%) participating in this study felt they had too many responsibilities at home (see Table 3). Girls, especially those at primary school ( $50 \%$ of those surveyed), strongly agreed that they had too many duties at home. Two thirds of the participating children, particularly secondary school going boys $^{3}$, also reported often missing school, which is likely to be due to the need to provide nursing care for household members and generate income.

\begin{tabular}{|c|c|c|c|c|c|c|c|}
\hline \multirow{2}{*}{\multicolumn{2}{|c|}{$\begin{array}{l}\text { Orphaned and vulnerable } \\
\text { pupils }\end{array}$}} & \multicolumn{2}{|c|}{$\begin{array}{l}\text { Primary school } \\
(n=28)\end{array}$} & \multicolumn{4}{|c|}{$\begin{array}{l}\text { Secondary } \\
\text { school }(n=27)\end{array}$} \\
\hline & & Girls & Boys & All & Girls & Boys & All \\
\hline \multirow{3}{*}{$\begin{array}{l}\text { I eat } \\
\text { enough } \\
\text { food most } \\
\text { days }\end{array}$} & $\begin{array}{l}\text { Strongly } \\
\text { agree }\end{array}$ & $25 \%$ & $4 \%$ & $29 \%$ & $15 \%$ & $22 \%$ & $37 \%$ \\
\hline & $\begin{array}{l}\text { Somewhat } \\
\text { agree }\end{array}$ & $25 \%$ & $14 \%$ & $39 \%$ & $19 \%$ & $15 \%$ & $33 \%$ \\
\hline & Disagree & $11 \%$ & $21 \%$ & $32 \%$ & $15 \%$ & $15 \%$ & $30 \%$ \\
\hline \multirow{3}{*}{$\begin{array}{l}\text { I have got } \\
\text { too many } \\
\text { duties at } \\
\text { home }\end{array}$} & $\begin{array}{l}\text { Strongly } \\
\text { agree }\end{array}$ & $50 \%$ & $25 \%$ & $75 \%$ & $30 \%$ & $26 \%$ & $56 \%$ \\
\hline & $\begin{array}{l}\text { Somewhat } \\
\text { agree }\end{array}$ & $4 \%$ & $11 \%$ & $14 \%$ & $7 \%$ & $11 \%$ & $19 \%$ \\
\hline & Disagree & $7 \%$ & $4 \%$ & $11 \%$ & $11 \%$ & $15 \%$ & $26 \%$ \\
\hline \multirow{3}{*}{$\begin{array}{l}\text { I often } \\
\text { miss } \\
\text { school }\end{array}$} & $\begin{array}{l}\text { Strongly } \\
\text { agree }\end{array}$ & $18 \%$ & $14 \%$ & $32 \%$ & $15 \%$ & $22 \%$ & $37 \%$ \\
\hline & $\begin{array}{l}\text { Somewhat } \\
\text { agree }\end{array}$ & $18 \%$ & $18 \%$ & $36 \%$ & $15 \%$ & $19 \%$ & $33 \%$ \\
\hline & Disagree & $25 \%$ & $7 \%$ & $32 \%$ & $19 \%$ & $11 \%$ & $30 \%$ \\
\hline
\end{tabular}

Table 3: Struggles faced by orphaned and vulnerable pupils

Everyday material struggles not only affected children's school attendance, but also their concentration and educational performance (Skovdal 2016). Primary and secondary school 
teachers reported that orphaned and vulnerable pupils came to school with empty stomachs and worried about their home situation, which affected their concentration in class. Echoing previous research from South Africa (Cluver et al. 2012; Watkins et al. 2014), Zambia (Day and Evans 2015), Tanzania and Uganda (Evans 2012a), young people with caring responsibilities experienced difficulties in arriving at school on time and in concentrating as well as in meeting the costs of school uniforms and materials. They often missed classes due to their caring responsibilities or their own illness for periods of a few days up to several months or dropped out of school permanently.

Young people's significant caring responsibilities and the structural barriers they face reveal the need for a broader ethic of care within school spaces, rather than the hitherto narrow focus of educational institutions. But what can schools and teachers do to alleviate children's care work in the face of such structural inequalities and very limited external support?

\section{'Caring about' and 'taking care of' orphaned and vulnerable children in schools?}

"We are here to teach. But we can't avoid the challenges facing orphaned and vulnerable children, we have to consider them and see what we can do, so we try to strike a balance" Deric, primary school teacher in Bondo District, Kenya.

Almost all participating pupils ( $90 \%$ of primary school pupils and $100 \%$ of secondary pupils) felt supported by teachers. These findings contrast with the much lower proportion of pupils who felt supported by neighbours (only a third of pupils) and community groups (less than a quarter of pupils surveyed), despite the fact that these are often the actors called upon in orphan-directed programmes (Skovdal et al. 2011).

Teachers commented that it was essential for them to know what was going on at home in order to support pupils. For them to differentiate between a 'lazy pupil' and a pupil who might be struggling due to challenges at home, teachers explained that they needed to understand the pupil's background, which could be a challenge in itself. HIV-related stigma and embarrassment of the home situation prevented some pupils from explaining why they were unable to attend school regularly, do homework or concentrate in class. As Peter, a primary school teacher explained:

"Because of stigma, pupils do not explain their situations. It our job to investigate the children's background. Only then will the teachers be able to help them [...]. As teachers we can offer guidance and counselling if we establish the truth about a particular child and we can also offer some little assistance and subsidize fees, and we can be 
considerate on certain issues, which require attention of others maybe outside the school".

Teachers spoke of several strategies they employed to establish a child's background, including being friendly and approachable so that pupils felt comfortable opening up. Some schools had designated guidance and counselling teachers whom the pupils were actively encouraged to approach and whom they valued. Linder, aged 18, studying at secondary school, commented:

"When I have a problem I can go to the guidance and counselling teacher and she will take my mind off that problem or in case she cannot she takes the problem to the staff so they can help me. So I would say my relationship with the teachers is good."

As this example shows, another strategy was to promote information sharing and open communication between teachers. Teachers arranged meetings to discuss the challenges of particular children and said they would not hesitate to visit the homes of struggling pupils or ask their parents to come to school to discuss the difficulties pupils faced. This reflects the first phase of the caring process: 'caring about', involving being attentive to the needs of others.

As Antony, a primary school teacher explained,

"The boy dropped out of school and I was asked to find out why. I learned the root cause was outside school. His guardians gave him too many duties. I called in the guardian so that we could resolve the situation".

Occasionally, when primary school-going children permanently abstained from school, teachers reported that they involved local chiefs, and even the police, to ensure pupils returned to school. There was however a recognition of the repercussions of forcing children to attend school, when their survival, and that of their relatives, was dependent on their care work and economic contribution to the household. Once teachers and the school leadership understood situations of vulnerability facing pupils, teachers and pupils reported that teachers were sympathetic and understanding - showing willingness to support orphaned and vulnerable pupils.

Once teachers were aware of pupils' difficult home situations, they were able to offer a range of informal support and flexibility in meeting school expenses. Such practices illustrate the second phase of the caring process: 'taking care of' (Tronto 1993), associated with teachers' responsibility to take action to meet pupils needs. Fifteen-year-old Evaline, studying in 
secondary school, explained how when she told a teacher about her difficulty in meeting the fee deadline, he showed flexibility and allowed her mother to pay later:

"When we were sent home for fees I couldn't pay. I went to my teacher and explained my problems and he allowed me to come to school and my mother to pay later."

Participants also reported that school leaders occasionally allowed fees and levies to be paid in-kind (e.g. as labour or food produce), on credit or in stages. Such flexibility was seen as necessary to prevent orphaned and vulnerable pupils from being sent home and hence missing school until money had been raised. Pupils and teachers also said that some teachers withheld punishment of orphaned and vulnerable pupils who were unable to do their homework, or who struggled to attend class on time.

\section{'Care-giving' and 'care-receiving': the emergence of an ethic of care in Kenyan schools?}

Not only did teachers 'care about' and 'take care of' pupils needs, but this research suggests that some teachers engaged in practical 'care-giving' and were responsive to pupils' experiences of receiving care, reflecting the third and fourth phases of Tronto's caring process. This suggests the emergence of an ethic of care in schools affected by the HIV epidemic, albeit based on informal support and the actions of individual teachers rather than on a more institutionalised, formal response to pupils' needs.

All of the young people interviewed gave examples of a teacher who had gone beyond the call of duty and provided orphaned and vulnerable pupils with school equipment paid for out of their own income. Although most examples referred to teachers who had bought pens and exercise books, some teachers bought school uniforms, books and even food for orphaned and vulnerable pupils. Some teachers also used their own funds to pay for the fees or levies of some primary school pupils. Joy (age 13) explained her drawing (see Figure 2) of a teacher who helped vulnerable pupils:

"There was a time when I was sent home for school levies, which was 100 Kenyan shillings $(\$ 1,20)$ only, and as always I went home and started fetching water for neighbours to earn money. Whilst doing this, this teacher sent another pupil to tell me to come back to school as she had paid that money. The teacher is very friendly to the students and she would not hesitate to help any that comes for some help". 
Figure 2: 'A supportive teacher' by Joy

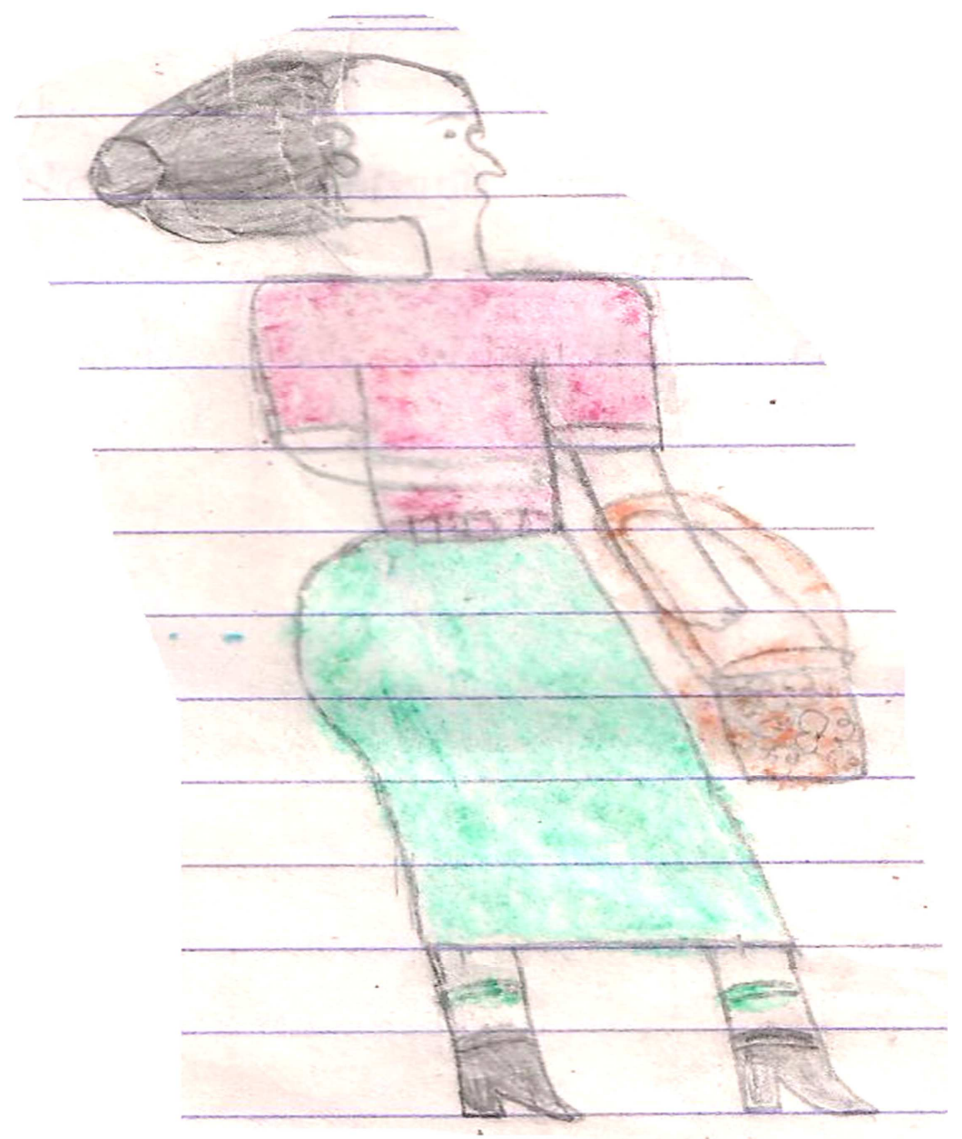

Further practices that reflect the 'care-giving' phase of Tronto's framework included individual teachers providing emotional support. Jane, a 16-year-old secondary school pupil, talked about a teacher who showed compassion and care, as well as material support (see Figure 3):

"This teacher has been an encouragement to me because she would always help me out when I am depressed. The teacher would share with me her life story, how she struggled in life to become the teacher she is today, she also used to be a young carer taking care of her aged grandmother and attending school at the same time. This encourages me to concentrate in class. She also gives me food when she is able to. This makes me happy because I have someone who cares for me and helps me through difficult times". 
Figure 3: 'An understanding teacher' by Jane

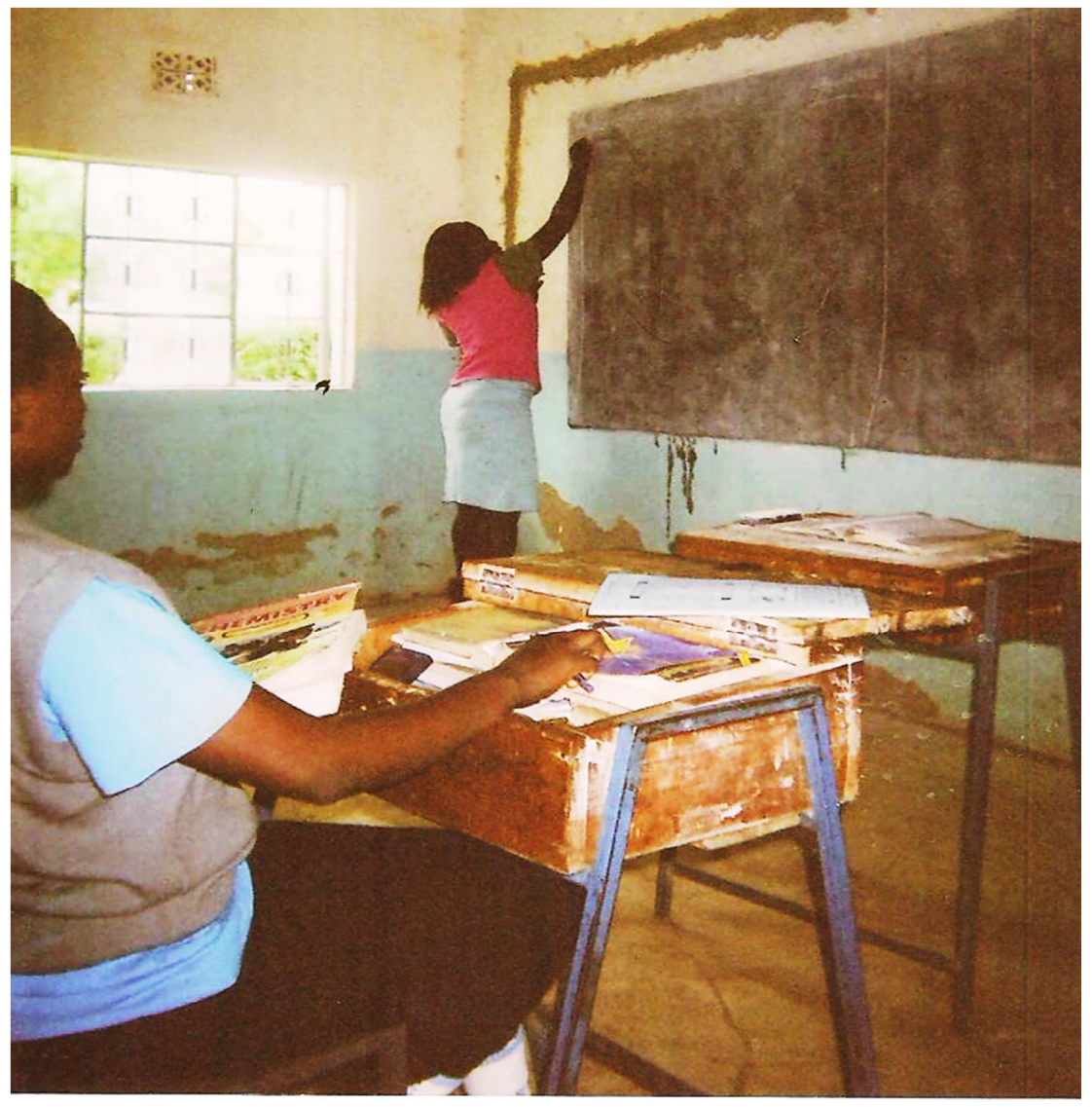

Thus, some teachers were depicted as engaging more directly in the practical (and often feminised) phase of 'care-giving', by providing emotional support and encouragement to struggling pupils. This shows a willingness to create a more caring, inclusive school environment. Jane's response to this care, which she highly valued and which she felt helped her to concentrate in class, could be characterised as the 'care-receiving' phase, associated with the ethical value of 'responsiveness'. This is only possible if there is good communication between those giving and receiving care (Bondi 2008).

Some teachers were reported to offer a higher level of care or to take immediate action when finding a child in an extremely vulnerable state and unable to attend classes. Examples included teachers offering vulnerable pupils short-term accommodation in their homes or extending care support to sick parents and guardians. Teachers from one secondary school noticed that the concentration of one of the brighter pupils in their class was rapidly deteriorating. The female pupil disclosed to a teacher that her mother was sick, which prompted a group of teachers from the school to come together and take the parent to the hospital for testing and treatment. A friend of the pupil commented that since receiving this 
care support from teachers (reflecting the 'care-giving' phase), which enabled her to access HIV treatment, the mother's condition had improved and her friend attended school regularly.

One example, however, provides evidence of a more institutionalised response to the needs of orphaned and vulnerable pupils. Young people reported that teachers sometimes initiated specific activities to support orphaned and vulnerable pupils, such as afterschool classes for struggling pupils or setting up afterschool clubs focused on developing life skills and establishing income generating activities, such as keeping livestock (goats, sheep and cows were mentioned by participants), or developing a seed nursery and planting kale within the school compound. Such afterschool clubs appear to address concerns about the potentially limited opportunities available to orphaned young people to learn life skills, including agricultural practices, from sick or deceased parents/relatives (Van Blerk et al. 2008; Evans, 2012b). Schools may thus represent an important site where young people's life skills and agricultural knowledge may be developed, in addition to growing food and generating income that may support vulnerable young people's education and nutrition in school.

It is clear that some teachers tried to provide a caring educational environment for orphaned and vulnerable children, which reflects the core ethical values associated with 'good care': attentiveness to pupils' needs, taking responsibility to meet these needs, drawing on their competencies and skills to provide care, and communicating with pupils to ensure the care was responsive and appropriate to their needs. However, as the next section highlights, such an ethic of care was not common to all teachers or school environments in the study locations.

\section{Competence to care? Constraints in the support of orphaned and vulnerable pupils}

While teachers generally 'care about' their pupils, the second, third and fourth phases of the caring process - 'taking care of' their needs, engaging in 'care-giving' and ensuring the care is responsive to the needs of pupils - were undermined by a lack of resources, limited competencies and sometimes discriminatory practices. Most of the teachers felt they were not equipped to deal with the hardships and educational needs of orphaned and vulnerable children, in terms of lacking the requisite skills (that they thought required specific training) and were faced with inadequate school resources (inadequate staffing, classrooms, teaching materials and so on). Some teachers, such as Tabitha, a primary school teacher, felt overworked and found it difficult to find time to engage in activities outside of teaching: "It is not that we are lazy. But the teaching work load is vast, making it difficult for us to get time to 
get involved in extracurricular activities". Such pressures and resource constraints undermined teachers' own ethical values and commitment to support their pupils.

Some teachers felt they were not in a position to provide for the material needs of orphaned and vulnerable pupils ('care-giving') within the home, viewing such support as beyond their remit or their individual means:

"There is no way a teacher can provide flour and everything to a household so that the child can come to school [..] I may just co-ordinate with people who may be able to help like the provincial administration to help us bring them back. As a teacher I do not have time to go out there and take care of such children." Peter, primary school teacher.

Because of these constraints, teachers were forced to make choices about whom they could support, a process that could lead to perceptions of gender discrimination among pupils.

Pupils suggested that some teachers' behaviour in response to lateness appeared to discriminate between boys and girls, reflecting wider gender norms that prioritised boys' education over girls'. Ava, a 17-year old secondary school pupil was responsible for paying for her own education (and had a disrupted school attendance record), whilst the secondary education of her twin brother was paid for by her father. Ava also cared for her sister and drew parallels between her access to education and that of her sister:

"She didn't manage to do her secondary education, she started well but my father refused to take her to school. My dad prefers boys over girls, and he normally says that there is nothing a girl can do to help him, she was told to go and do the small [vocational] trainings."

Q: How did it make you feel when your dad told your sister that there is nothing a girl can do to help him?

I felt pain as the same applies to me. When I cleared [completed] my primary school education I was together with my twin brother and my dad took him to secondary school [she started crying]".

Ava also observed such discriminatory gender norms in the classroom. 'Polite and quiet' girls who were late were made to wait to join the classroom, while boys who 'rudely opened the door themselves' joined the classroom without being challenged by teachers.

Furthermore, at all the participating schools, a culture of prioritising the support needs of higher achieving orphaned and vulnerable pupils was evident. As Edmond (age 15, secondary school pupil) explained through a drawing (see Figure 4): 
"The help that students get from my school is always given to good performing but vulnerable students who cannot afford school items".

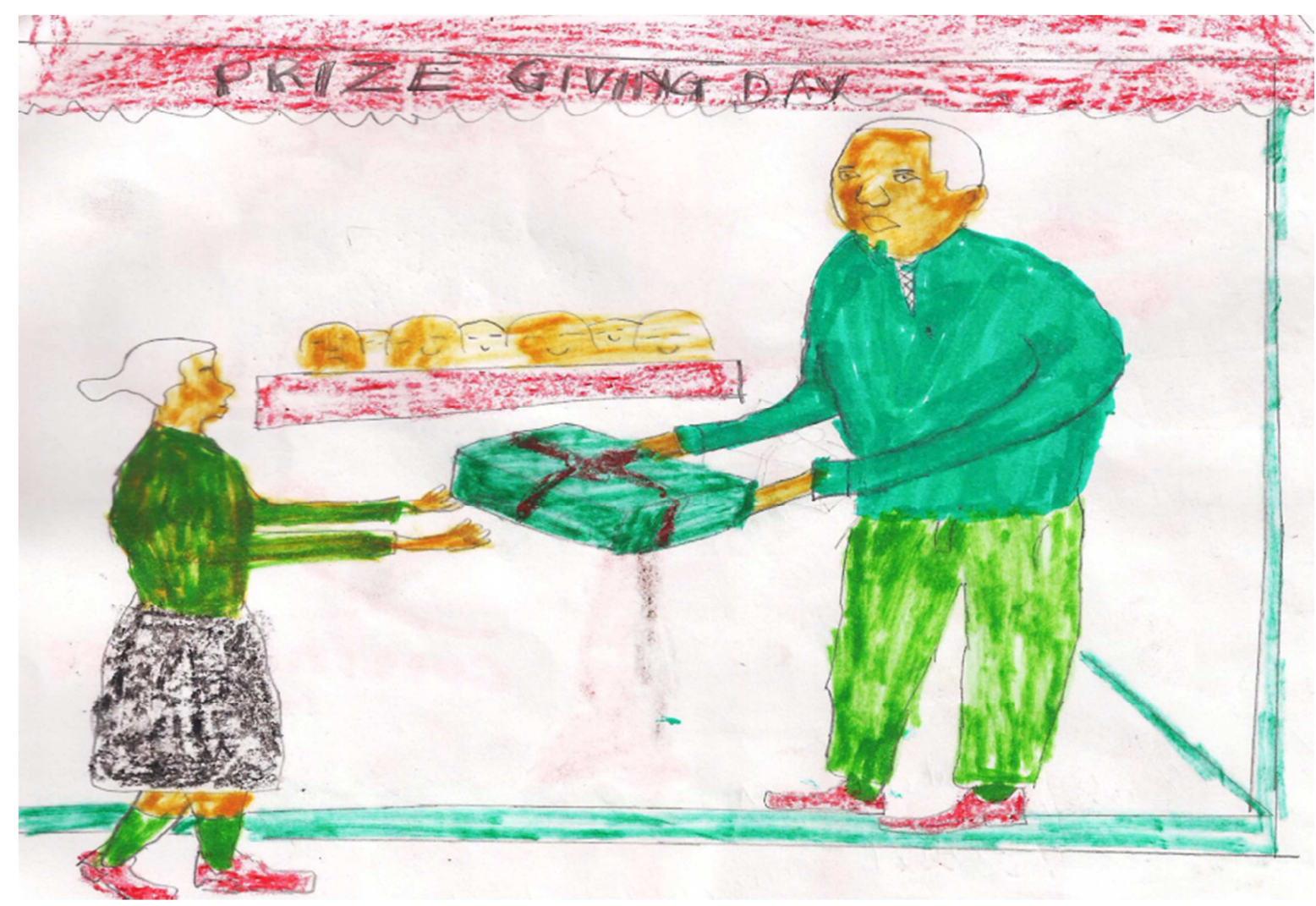

Figure 4

Pupils reported that teachers were more likely to identify higher achieving orphaned and vulnerable pupils for NGO sponsorship. Similarly, some teachers said that they were less motivated to meet the educational costs of a child whose academic performance was poor. As Maggy, a primary school teacher, explained, "it's very difficult to invest where you know you will not reap anything".

Such perspectives reflect global development discourses that primarily value education as an investment in human capital, which demands some recompense in future. These attitudes and practices appear to be driven by neoliberal demands, rather than those based on an ethic of care and resulted in the preferential treatment of the few higher achieving pupils, while other pupils with similar material needs were overlooked. This could result in resentment and competition among pupils for teachers' attention and the limited support available, and could reinforce processes of exclusion, since pupils' lower educational performance was often a result of caring responsibilities, poverty and irregular school attendance. 


\section{Conclusion}

This research has shown how young people's everyday struggles of social reproduction in the context of the HIV epidemic in rural Kenya can lead to time scarcity and barriers to education, supporting research from elsewhere in Eastern and Southern Africa. Our findings, however, also provide glimpses of schools as spaces of care, participation and support for orphaned and vulnerable pupils. Drawing on Tronto's (1993) framework, the complex, interrelated nature of different phases of the caring process and associated ethical values are evident in the range of strategies and practices teachers engaged in to 'take care of' and 'care for' orphaned and vulnerable pupils. The vast majority of pupils perceived their teachers as sources of support, in contrast to the much smaller proportion who viewed neighbours and community groups in this way. The research suggests that teachers were, 'providing room' for the children to be vulnerable (Theron and Engelbrecht 2012), recognised their care needs, and demonstrated the ethical values of attentiveness, responsibility, compassion and responsiveness in their interactions with pupils within educational spaces.

While the practices we have discussed do not yet reflect Tronto's (2013) vision of a 'caring with' democratic society, an ethic of care is emerging in rural Kenyan schools, thereby moving 'care' from the margins to a more central place in school environments and teachers' practices. While most teachers 'care about' the needs of orphaned and vulnerable pupils, reflecting the first phase of the caring process, greater support is needed to adopt a more holistic 'caring with' approach, which facilitates the participation of school staff, pupils, relatives and community members in deciding on the appropriate assignment of caring responsibilities. This may involve school staff, government social welfare workers, NGOs, community leaders or other community members 'taking care of' orphaned and vulnerable pupils and assuming responsibility, engaging more directly in 'care-giving' and in ensuring care is responsive to children's needs (the second, third and fourth phases in Tronto's 1993 framework). The third 'care-giving' phase of the caring process, however, is associated with the ethical value of 'competence' to provide care, highlighting the need for teachers, school staff or other support workers to have the appropriate skills, training, resources and institutional support to facilitate this important care work. The fourth phase, 'care-receiving', and the associated ethical value of 'responsiveness', is also crucial to ensure that the care provided is appropriate and meets orphaned and vulnerable children's and family members' needs and necessarily involves good communication.

Teachers' responses to the struggles of orphaned and vulnerable pupils must be seen within the context of resource constraints and wider structural inequalities that shape care work and 
school learning environments in Kenya and other African countries. Such processes include the neoliberal educational project to reproduce the next generation of workers (Ansell 2008), gender discrimination in educational spaces (UNICEF 2011), the policy emphasis on homebased care and the devolving of responsibility to care for those who are sick, disabled or have other care needs from the state to families and communities (Ogden, Esim, and Grown 2006). Furthermore, schools and communities often reproduce dominant gender norms which prioritise boys' education over girls' and which de-value care and daily social reproductive work, linked to its feminisation and association with women's and girls' 'natural' nurturing qualities (Evans and Thomas 2009; Tronto 1993). This has detrimental impacts on girls' educational attendance and outcomes, which is regarded as having major consequences for sustainable development (UNICEF 2011). This may also lead to a feminization of 'care' within school spaces if 'care-giving' roles are assigned more to female teachers than male teachers, thereby reproducing hegemonic gender norms.

Teachers in all six schools participating in this study reported going beyond the call of duty and investing their own time and money on pupils in need on an informal basis. Whilst this is laudable, it is not a sustainable or viable strategy to support all orphaned and vulnerable pupils in Eastern and Southern Africa (Campbell et al. 2014). Rather than devaluing such care work or seeing such responses as a free resource, there is a need to foster a holistic 'caring with' approach, tackle gender discrimination and seek to embed teachers' informal caring practices within an institutional framework that is more attuned to the practical, material, emotional and educational care needs of orphaned and vulnerable children. Such an approach, which enables teachers, pupils and other development actors to participate as fully as possible in deciding on the assignment of caring responsibilities, may help to address the considerable educational barriers which hinder the inclusion, participation and well-being of girls and boys who are orphaned and vulnerable.

\section{Acknowledgements:}

We thank the pupils and teachers participating in this study. We also thank the Norwegian Research Council for funding this project (project number: 204219) and colleagues at the Department for Health Promotion and Development, University of Bergen (where the first author was based during the time of the study), for general support. We would also like to thank Jacob Onyango, Caroleen Akinyi Ouma, Nancy Otieno and Vincent Onyango Ogutu for research assistance. Also thanks to Tatek Abebe for comments on an earlier draft of this paper. 


\section{Endnotes}

1. Space does not permit discussion of other authors' contributions to theoretical debates on care ethics.

2. This qualitative study was granted ethical approval by the Norwegian Social Science Data Services (27655/AH/RF) and The National Council for Science and Technology in Kenya (NCST/RCD/12A/012/043B). The Kenyan Ministry of Education also granted permission.

3. In view of the priority often placed on boys' education and the fact that girls felt that they had too many responsibilities, boys may have more readily reported missing school, while girls may have underestimated the impacts of caring on their education or perhaps have been more used to juggling domestic, care and paid work demands with schooling.

\section{REFERENCES}

Ansell, N. (2008). Substituting for Families? Schools and Social Reproduction in AIDS-affected Lesotho. Antipode, 40(5), 802-824.

Attride-Stirling, J. (2001). Thematic networks: An analytic tool for qualitative research. Qualitative Research, 1(3), 385-405.

Bhana, D., Morrell, R., Epstein, D., \& Moletsane, R. (2006). The hidden work of caring: teachers and the maturing AIDS epidemic in diverse secondary schools in Durban. Journal of Education, 38, 5-23.

Bondi, L. (2008). On the relational dynamics of caring: a psychotherapeutic approach to emotional and power dimensions of women's care work. Gender, Place and Culture, 15(3), 249-265.

Campbell, C., Andersen, L., Mutsikiwa, A., Madanhire, C., Nyamukapa, C., \& Gregson, S. (2016). Can Schools Support HIV/AIDS-Affected Children? Exploring the'Ethic of Care'amongst Rural Zimbabwean Teachers. PloS one, 11(1).

Campbell, C., Andersen, L., Mutsikiwa, A., Madanhire, C., Skovdal, M., Nyamukapa, C., \& Gregson, S. (2014). Children's representations of school support for HIV-affected peers in rural Zimbabwe. BMC Public Health, 14(1), 402.

Campbell, C., Andersen, L., Mutsikiwa, A., Pufall, E., Skovdal, M., Madanhire, C., Nyamukapa, C., \& Gregson, S. (2015). Factors shaping the HIV-competence of two primary schools in rural Zimbabwe. International Journal of Educational Development, 41, 226-236.

Cluver, L., Operario, D., Lane, T., \& Kganakga, M. (2012). "I Can't Go to School and Leave Her in So Much Pain": Educational Shortfalls Among Adolescent 'Young Carers' in the South African AIDS Epidemic. Journal of Adolescent Research, 27(5), 581-605.

Collins, D., \& Coleman, T. (2008). Social Geographies of Education: Looking Within, and Beyond, School Boundaries. Geography Compass, 2(1), 281-299.

Day, C., \& Evans, R. (2015). Caring Responsibilities, Change and Transitions in Young People's Family Lives in Zambia. Journal of Comparative Family Studies, 46(1).

Evans, R. (2012a). Sibling caringscapes: Time-space practices of caring within youth-headed households in Tanzania and Uganda. Geoforum, 43(4), 824-835. 
Evans, R. (2012b). Safeguarding inheritance and enhancing the resilience of orphaned young people living in child-and youth-headed households in Tanzania and Uganda. African Journal of AIDS Research, 11(3), 177-189.

Evans, R. (2014). Parental death as a vital conjuncture? Intergenerational care and responsibility following bereavement in Senegal. Social \& Cultural Geography, 15(5), 547-570.

Evans, R., \& Thomas, F. (2009). Emotional interactions and an ethics of care: Caring relations in families affected by HIV and AIDS. Emotion, Space and Society, 2(2), 111-119.

Ferreira, R., \& Ebersöhn, L. (2011). Formative evaluation of the STAR intervention: improving teachers' ability to provide psychosocial support for vulnerable individuals in the school community. African Journal of AIDS Research, 10(1), 63-72.

Fonner, V. A., Armstrong, K. S., Kennedy, C. E., O’Reilly, K. R., \& Sweat, M. D. (2014). School based sex education and HIV prevention in low-and middle-income countries: a systematic review and meta-analysis. PloS one, 9(3), e89692.

Foster, J., Addy, N. A., \& Samoff, J. (2012). Crossing borders: Research in comparative and international education. International Journal of Educational Development, 32(6), 711-732.

GoK. (2013). Siaya County Integrated Development Plan 2013-2017. Siaya: County of Siaya, Government of Kenya.

Hanrahan, K. B. (2015). Living Care-Fully: The Potential for an Ethics of Care in Livelihoods Approaches. World Development, 72, 381-393.

Hoadley, U. (2007). Boundaries of care: the role of the school in supporting vulnerable children in the context of HIV and AIDS. African Journal of AIDS Research, 6(3), 251-259.

Khanare, F. (2012). Schoolchildren affected by HIV in rural South Africa: schools as environments that enable or limit coping. African Journal of AIDS Research, 11(3), 251-259.

Lawson, V. (2007). Geographies of care and responsibility. Annals of the Association of American Geographers, 97(1), 1-11.

McLaughlin, C., Swartz, S., Cobbett, M., \& Kiragu, S. (2015). Inviting Backchat: How schools and communities in Ghana, Swaziland and Kenya support children to contextualise knowledge and create agency through sexuality education. International Journal of Educational Development, 41, 208-216.

Mwoma, T., \& Pillay, J. (2015). Psychosocial support for orphans and vulnerable children in public primary schools: Challenges and intervention strategies. South African Journal of Education, 35(3), 1-9.

NACC. (2014). Kenya AIDS Response Progress Report 2014 - Progress towards Zero. Nairobi: National AIDS Control Council (NACC).

Noddings, N. (2012). The caring relation in teaching. Oxford Review of Education, 38(6), 771-781.

Nordveit, B. (2010). Schools as Agencies of Protection in Namibia and Swaziland: Can They Prevent Dropout and Child Labor in the Context of HIV/AIDS and Poverty? Comparative Education Review, 54(2), 223-242.

Ogden, J., Esim, S., \& Grown, C. (2006). Expanding the care continuum for HIV/AIDS: bringing carers into focus. Health Policy Plan, 21(5), 333-342.

Skovdal, M. (2008). "I washed and fed my mother before going to school": Understanding the psychosocial cost of children providing chronic care for adults affected by HIV/AIDS in Western Kenya Paper presented at the British Academy UK-Africa Academic Partnership on Chronic Disease - Chronic disease and African Communities: Research, Practice and Policy, London School of Economics, 23-24 June.

Skovdal, M (2016) "It's because they care": Understanding pathways to classroom concentration problems among HIV-affected children and youth in western Kenya. AIDS Care (in press).

Skovdal, M., \& Campbell, C. (2015). Beyond education: What role can schools play in the support and protection of children in extreme settings? International Journal of Educational Development(41), 175-183. 
Skovdal, M., Mwasiaji, W., Webale, A., \& Tomkins, A. (2011). Building orphan competent communities: experiences from a community-based capital cash transfer initiative in Kenya. Health policy and planning, 26(3), 233-241.

Skovdal, M., Webale, A., Mwasiaji, W., \& Tomkins, A. (2013). The impact of community-based capital cash transfers on orphan schooling in Kenya. Development in practice, 23(7), 934-943.

Theron, L., \& Engelbrecht, P. (2012). Caring Teachers: Teacher-Youth Transactions to Promote Resilience. In M. Ungar (Ed.), The Social Ecology of Resilience: A Handbook of Theory and Practice (pp. 265-280). New York: Springer.

Tronto, J. C. (1993). Moral boundaries: A political argument for an ethic of care: Psychology Press.

Tronto, J. C. (2013). Caring democracy: markets, equality, and justice: NYU Press.

UNICEF. (2009). Child-Friendly Schools Manual. New York: UNICEF (URL: http://www.unicef.org/publications/index 49574.html retrieved 02 October 2014).

UNICEF. (2011). State of the World's Children 2011. New York: UNICEF.

Van Blerk, L., \& Ansell, N. (2007). Alternative strategies for care giving in the context of AIDS in Southern Africa: complex strategies for care. Journal of International Development, 19, 865884.

Van Blerk, L., Ansell, N., Robson, E., Hadju, F., \& Chipeta, L. (2008). Youth, AIDS and rural livelihoods in southern Africa. Geography Compass, 2(3), 709-727.

Wang, C., \& Burris, M. (1997). Photovoice: Concept, Methodology, and Use for Participatory Needs Assessment. Health Education \& Behaviour, 24(3), 369-387.

Watkins, J., Sello, O., Cluver, L., Kaplan, L., \& Boyes, M. (2014). 'At school I got myself a certificate': HIV/AIDS Orphanhood and Secondary Education: a Qualitative Study of Risk and Protective Factors. Global Social Welfare, 1(3), 111-121. 